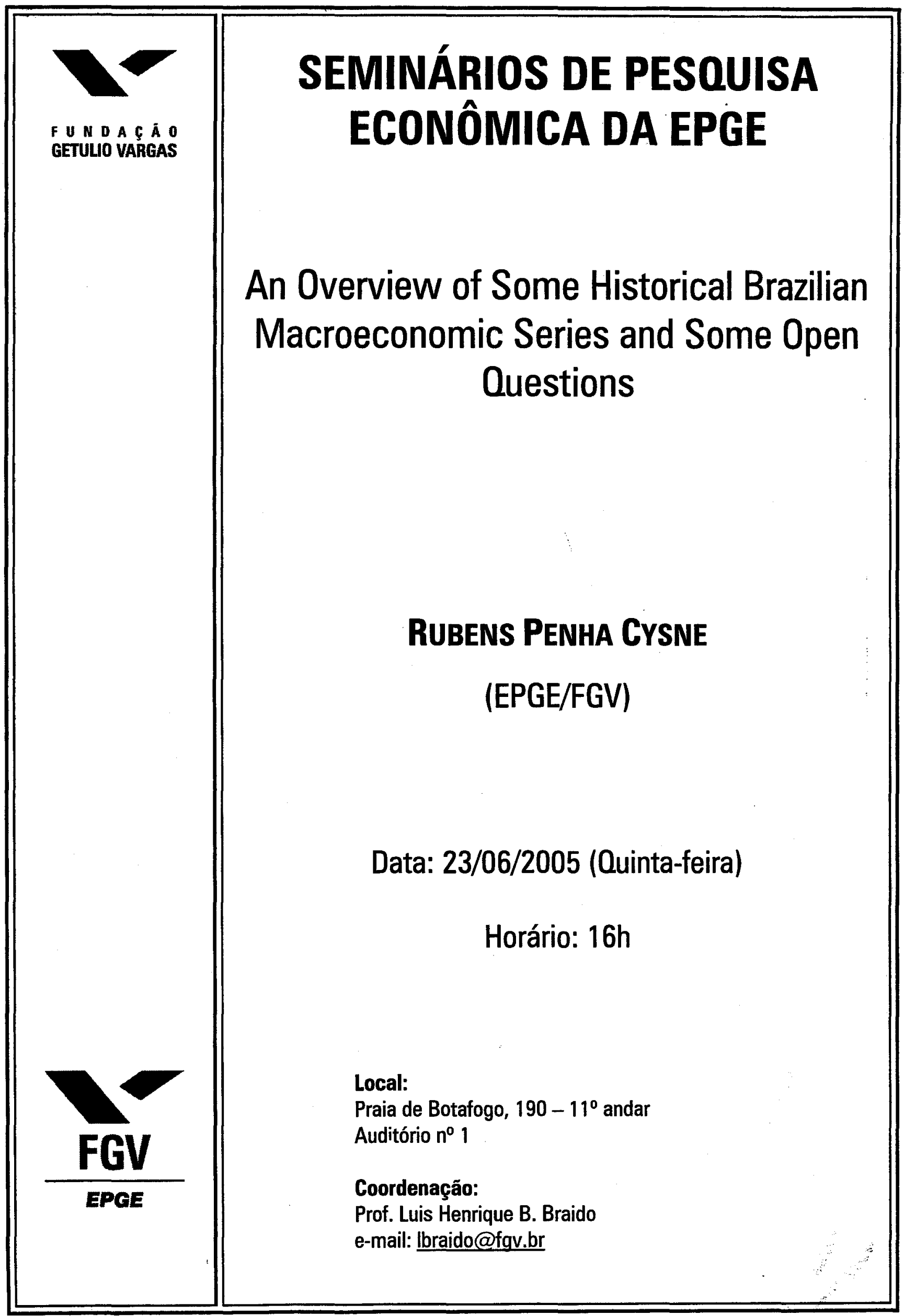




\title{
An Overview of Some Historical Brazilian Macroeconomic Series and Some Open Questions*
}

\author{
Rubens Penha Cysne ${ }^{\dagger}$
}

June 23, 2005

\begin{abstract}
This paper presents an overview of the Brazilian macroeconomy by analyzing the evolution of some specific time series. The presentation is made through a sequence of graphs. Several remarkable historical points and open questions come up in the data. These include, among others, the drop in output growth as of 1980, the clear shift from investments to government current expenditures which started in the beginning of the $80 \mathrm{~s}$, the notable way how money, prices and exchange rate correlate in an environment of permanently high inflation, the historical coexistence of high rates of growth and high rates of inflation, as well as the drastic increase of the velocity of circulation of money between the 70 s and the mid-90s. It is also shown that, although net external liabilities have increased substantially in current dollars after the Real Plan, its ratio with respect to exports in 2004 is practically the same as the one existing in 1986; and that residents in Brazil, in average, owed two more months of their final income (GNP) to abroad between 1995-2004 than they did between 1990 and 1994. Variance decompositions show that money has been important to explain prices, but not output (GDP).
\end{abstract}

*Work in Progress. Please do not cite or quote. Key Words: Brazilian Economy, Money, Prices, Output, Balance of Payments, Investments, Inflation. JEL Classifications: E0, G0, H0, N1 and O1.

†Professor at the Graduate School of Economics of the Getulio Vargas Foundation and a Visiting Scholar at the Department of Economics of the University of Chicago. E mail: rpcysne@uchicago.edu. 


\section{Introduction}

This paper provides a bird's eye view of the Brazilian macroeconomy within different periods of time. The analyses are carried out through the graphical view of some specific time series. For each series, the period of time contemplated in the study coincides with the period in which the data is digitally available in primary data bases ${ }^{1}$. The series go as far in the past as 1900, the first year for which there is an estimate of Brazilian GDP. All other series start in 1947 or later, due to the unavailability of official data concerning previous periods. In some cases, the equivalent series for the U.S. is displayed for the purpose of comparison.

A second objective of the paper, besides summing up historic economic information about Brazil, is raising some questions the answers of which are still open to economic research.

The paper proceeds as follows. Section II concentrates on the GDP growth between 1900 and 2004, taking the U.S. as a benchmark. Sections $I I I$ and $I V$ deal, respectively, with capital formation and public finance. Section $V$ concentrates on money and prices and section $V I$ on the foreign sector (balance of payments) and exchange rates. Section VII points out some open macroeconomic questions. Finally, section VIII concludes.

\section{GDP}

Figure 1 presents the evolution of the Brazilian and of the U.S. real GDP (Gross Domestic Product) between 1900 and 2004. In both graphs, for the

purpose of comparison, the $y$-axis has been arbitrarily normalized to start at one. Because I am using logarithmic data, rates of growth can be easily inferred by taking the difference between $y$-coordinates at different points of time.

\footnotetext{
${ }^{1}$ I call primary data bases those provided by the federal government (including Banco Central do Brasil, Tesouro Nacional, Ministério da Fazenda, Ministério do Planejamento, Fundação IBGE and IPEA) and the Fundação Getulio Vargas. The respective sources of each time series used in the work are presented in Appendix.
} 

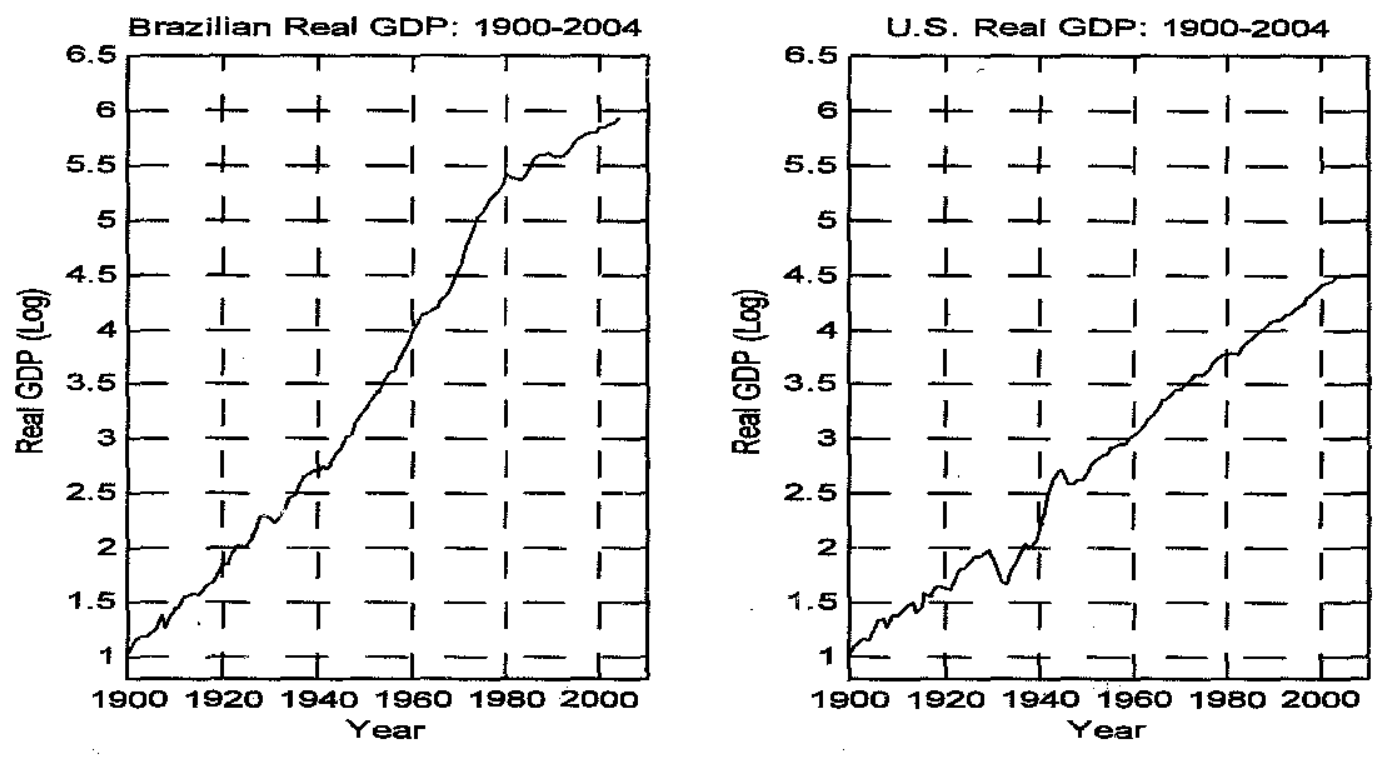

Figure 1

Regarding the Brazilian economy, one point that comes up in the left panel of Figure 1 is the break in the historical rate of GDP growth in the beginning of the eighties. Average growth was $5.68 \%$ between 1900 and 1980 and just $2.11 \%$ between 1980 and 2004, totalling $4.85 \%$ per year in the whole period. This can be inferred from the left panel of Figure 1 by drawing a straight line connecting the data in 1900 an 1980, extrapolating it to 2004, and subtracting its y-coordinate in 2004 from the $y$-coordinate of the original data.

If the Brazilian economy had kept its $1900-1980$ historical growth as of 1980 , the GDP and the per-capital income in 2004 would have been around 2.28 times the one which actually prevailed. In Reais (Brazilian present monetary unit) of 2004, this would mean a per capita domestic income around $R \$ 23,014$, instead of just $R \$ 10,094$. In average dollars of $2004, U \$ 7,865$. 3 , instead of $U \$ 3,449.8^{2}$.

Would it be the case that the growth decline in the 80s was somehow associated with a similar downturn of the industrialized economies?

The right panel of Figure 1 presents the evolution of the United States GDP for the same period. Average growth for the United States reached

\footnotetext{
${ }^{2}$ The average sale values of the dollar in 2003,2004 and from Jan 1 to June 02 of 2005 were, respectively, $\mathrm{R} \$ 3.071$, $\mathrm{R} \$ 2.926$ and $R \$ 2.621$.
} 
between 1900 and 1980 and $3.14 \%$ between 1980 and 2004. Repeating the calculations mentioned above for Brazil, if the United States had grown as of 1980 at its $1900-1980$ rate, the ratio between projected real GDP and actual real GDP would have reached just 1.09 in 2004, in contrast to the ratio of 2.28 for Brazil. Assuming that the behavior of the remaining industrialized countries could be approximated by that of the U.S. economy, the answer to the question posed in the preceding paragraph is clearly negative. It looks like most of the Brazilian loss of GDP after the 80s is to be explained by its own economic policies, rather than by external factors.

The calculations mentioned so far pertain to a type sometimes found in aistiy st: of the Brazilian economy. Even though the numbers do point out in the right direction, a more careful extrapolation provides different numbers.

The figures inferences above are too dependent on the points in time in which they are taken (respectively, 1900, 1980 and 2004). Extrapolating the GDP of a certain economy at a certain point in time is not a good practice because at this time this economy could be in different positions of its business cycle ${ }^{3}$. A way of dealing with this problem is estimating the average rates of growth based on a least-squares approximation, rather than on point estimates ${ }^{4}$.

Figure 2 repeats Figure 1, this time adding an extrapolation to the 19812005 period based on a $1900-1980$ least-squares fit.

\footnotetext{
${ }^{3} \mathrm{~A}$ second point is that the calculations are deterministic, and have not taken into consideration the different shocks that can impact long-run levels of GDP. In this paper I shall not be concerned about this fact.

${ }^{4} \mathrm{~A}$ log-linear trend can be interpreted as a rough estimation of potential output, which is used in the measurement of output gap. For the historical evolution of ideas concerning the measurement of potential output and output gap, see Okun (1962), Clark (1979 and 1982), Braun (1990) and Estrella and Mishkin (1999).
} 

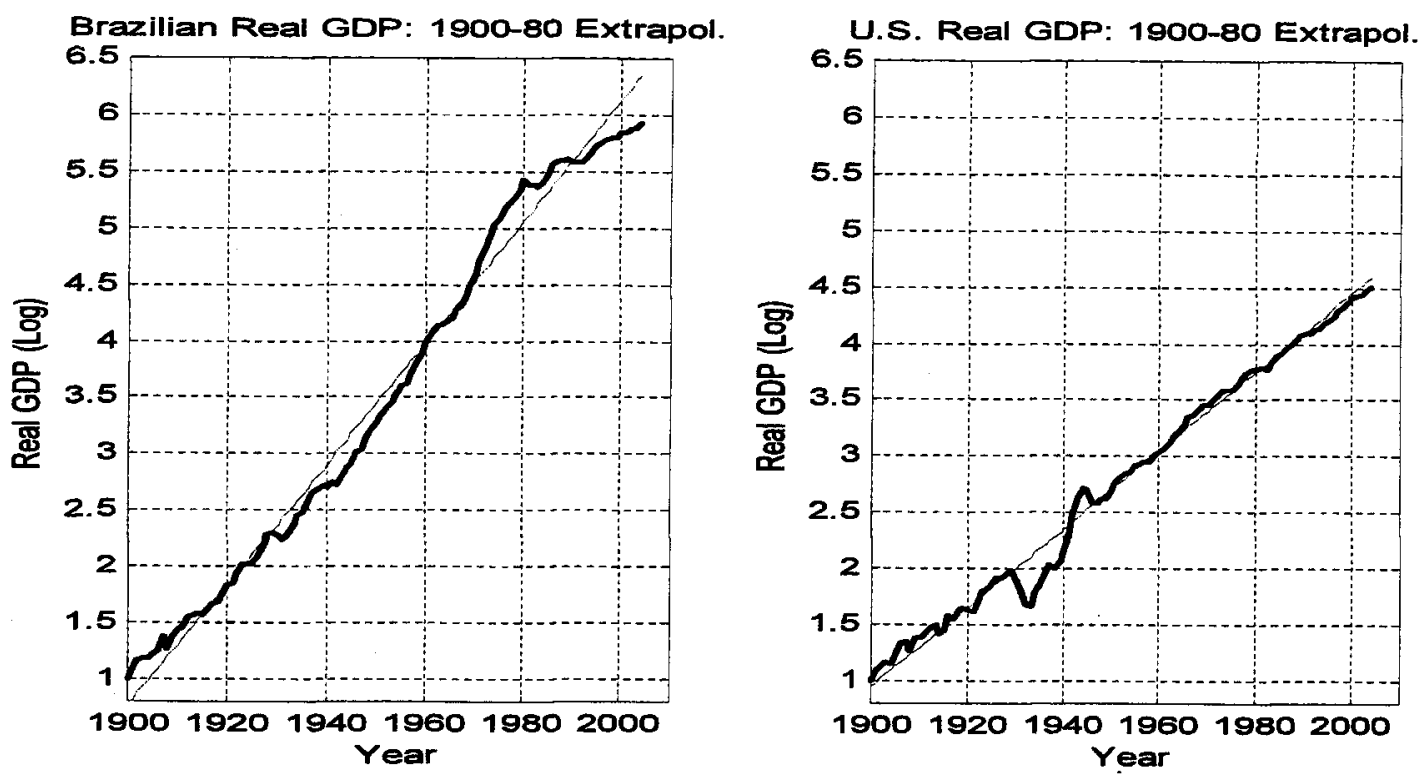

Figure 2

These alternative calculations indicate a "GDP loss" of just $52.08 \%$ for Brazil between 1980 and 2004, instead of the $128 \%$ reported before. The reason for such a discrepancy is that, as one can observe from the left panel of Figure 2, the output in 1980 was above the potential output determined by the log-linear trend used in the projections.

The change of procedure does not affect the number for the United States. Under the alternative methodology based on least-squares log-linear extrapolation the "lost GDP" for the United States reads 9.06\% (against $9.0 \%$ before).

A comparison between both graphs shows that Brazil has grown a way more than the United States during the $20^{\text {th }}$ century. Maybe a good example of a catch-up of a latecomer.

\section{Investments}

Figure 3 presents the capital formation, as a fraction of GDP, since 1947: The red line (here and in the figures to come) shows the trend obtained with a Hodrick-Prescott (HP) filter. 


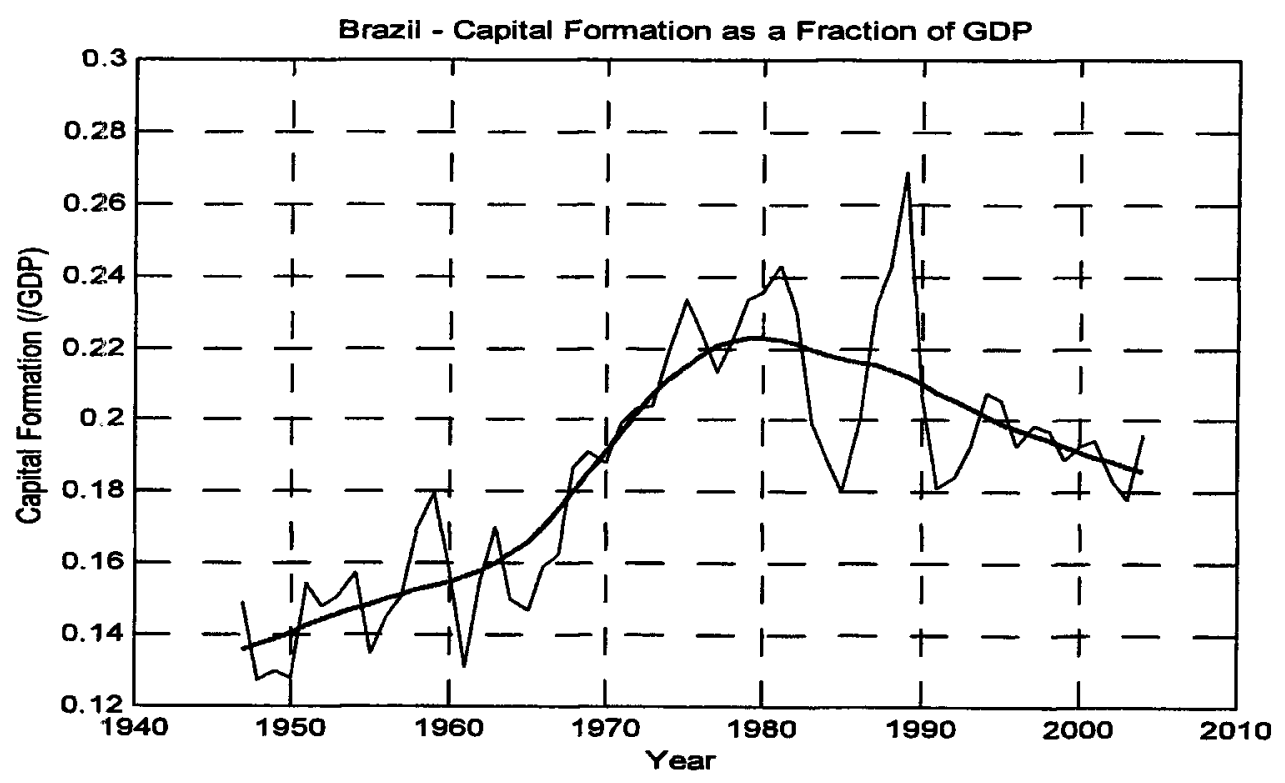

Figure 3

Capital formation increases till the end of the eighties. By this time, the large investment projects initiated under the military governments started to cease, and capital formation starts to decline.

The situation seems worse when one consider capital formation with 1980 prices, as displayed by Figure 4 (this time, as of 1970 only): 


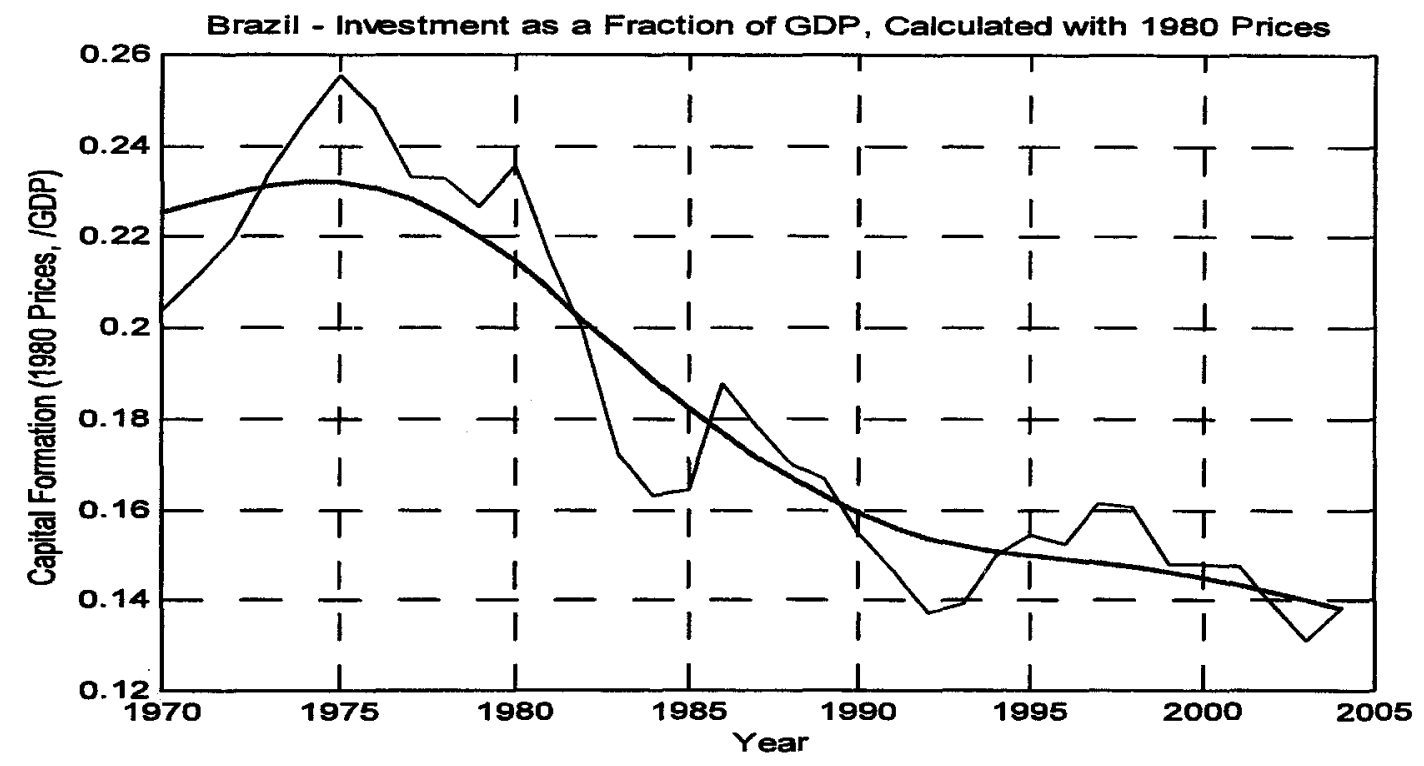

Figure 4

This decrease of investments is certainly to be included among the explanations concerning the fall of GDP growth as of 1980.

\section{Public Finance}

At the same time in which capital formation started decreasing in the beginning of the 80 s, public consumption, which includes mostly wage payments in the three administrative public levels (federal, state and local governments), started increasing. In twenty years, it practically doubled. Figure 5 shows this point quite clearly: 


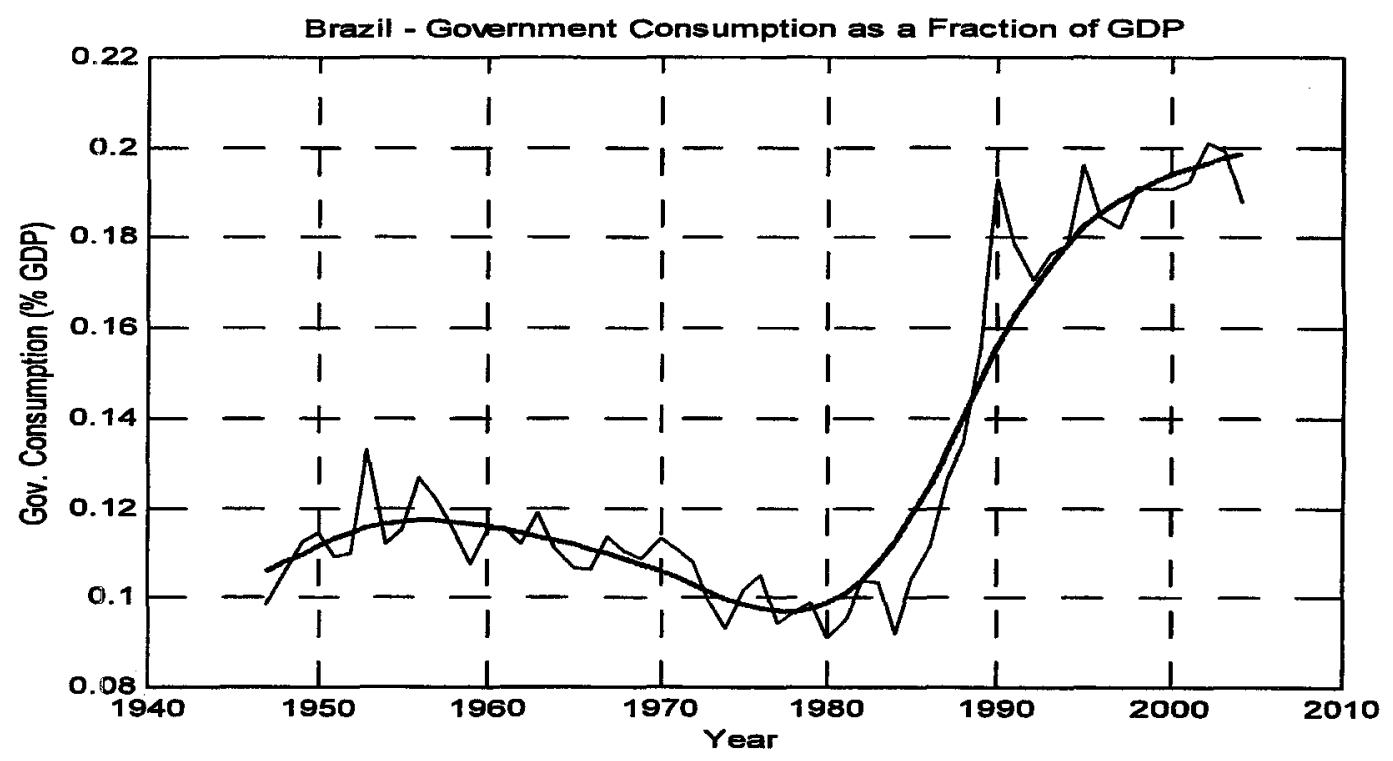

Figure 5

Taxes as a percentage of GDP, on the other hand, have kept their increasing trend as of 1990:

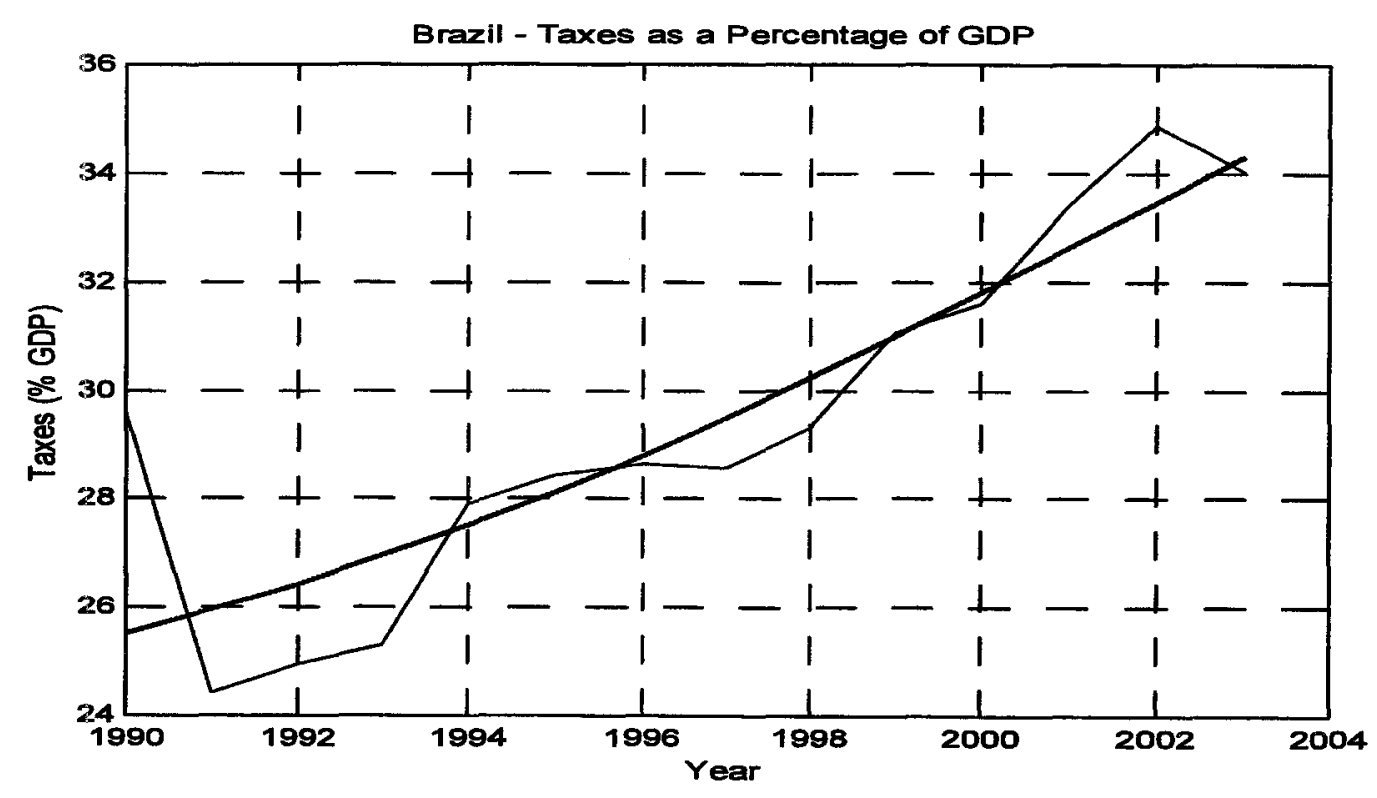

Figure 6 
Net public debt as a percentage of GDP, as shown in Figure 7, have increased steadily between 1996 and 2002, showing a small reversion between 2002 and the 2005:

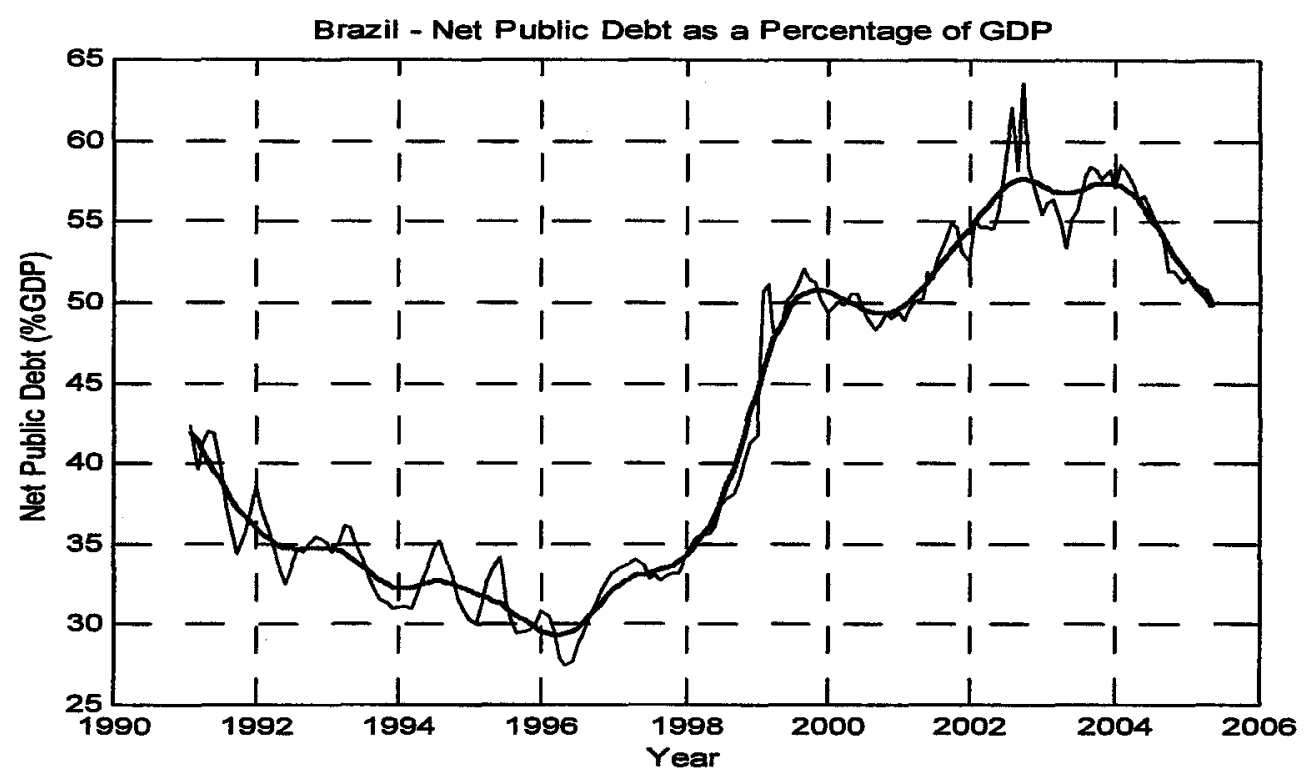

Figure 7

Another fiscal variable largely used in Brazil is the Operational Net Public Borrowing Requirements (NPBR). This variable is equal to the deficit calculated with real interests plus the inflation tax and encompasses not only the three public administrative levels but also state enterprises and public social security. When the inflation tax is negligible, the operational defict translates precisely the variation of the real value of the net indebtness of the government. Figure 8 shows the evolution of this variable between 1992 and 2005, in a 12-month moving sum. As usual, the red line translates the trend. The negative values presented as of 2003 are associated with the fall of the net indebtness shown in the preceding figure. 


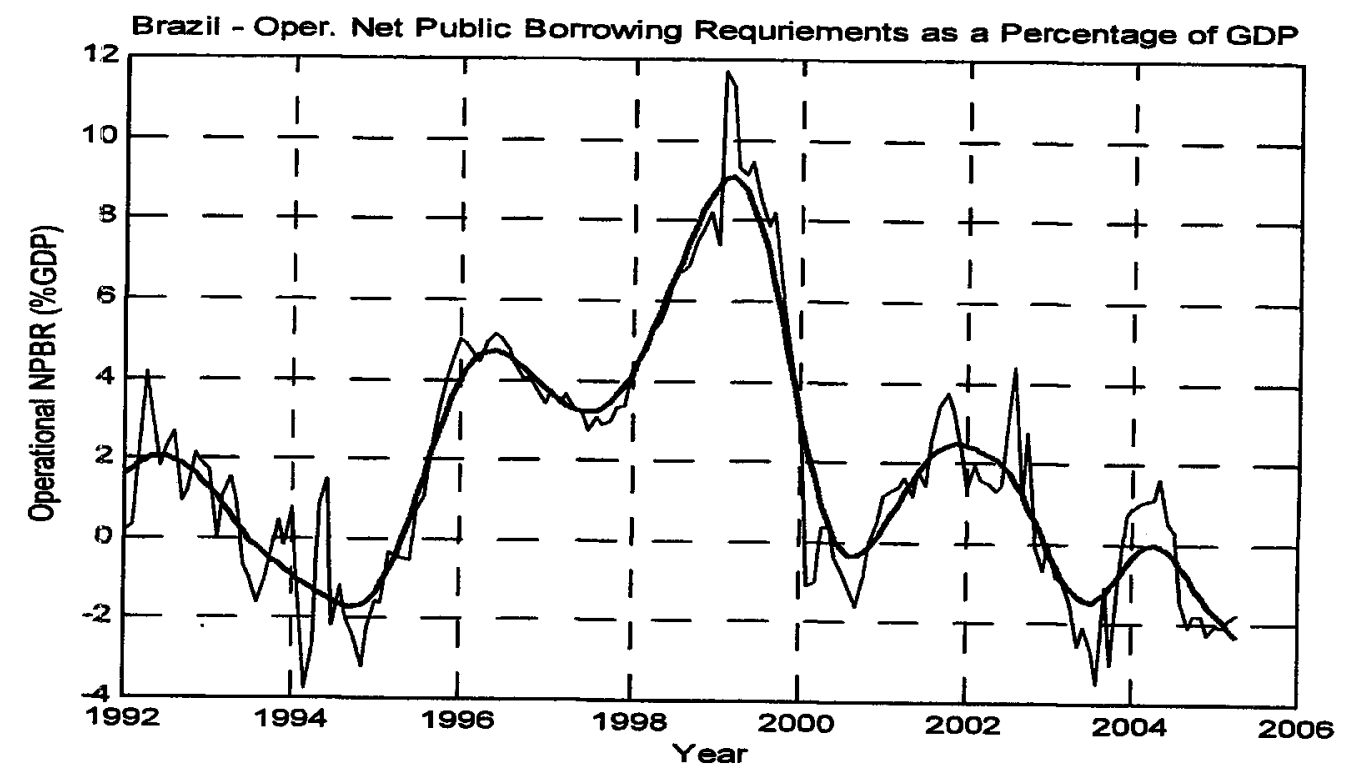

Figure 8

\section{Money and Prices}

Figure 9 below shows the long-run relationship between money $(M 1)$ and prices in Brazil (left panel) and in the United States (right panel).

The visual correlation (numerically, 0.994) in the Brazilian case is remarkable. As before, in both cases an arbitrary normalization is done in order to have the $y$-axis starting at one. This is trivial for prices, which are represented by an index. Regarding $M 1$, the normalization implies redefining the unit of account. In any case, what matters are the rates of growth implied by the differences of the $y$-coordinates at different points of time. 

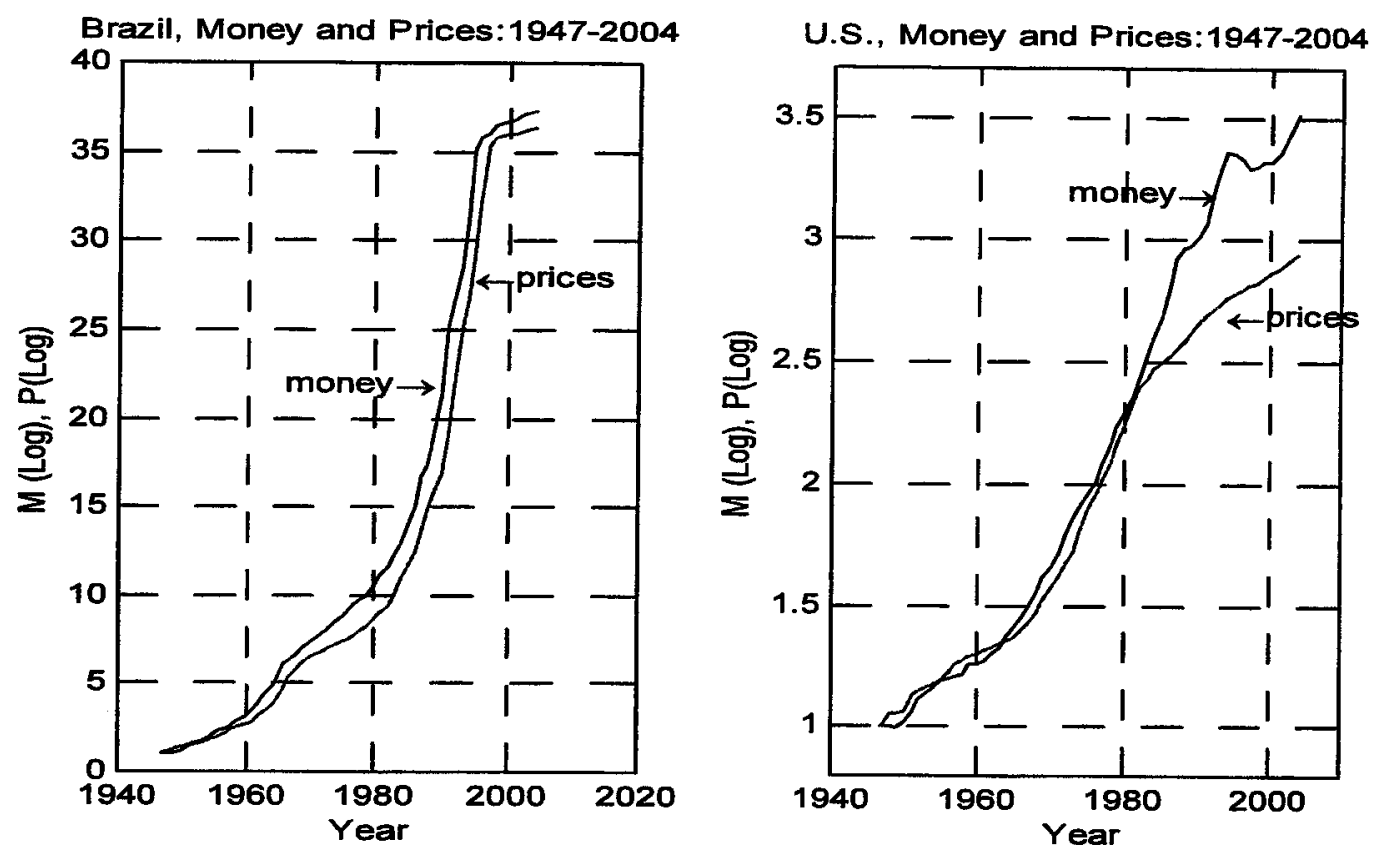

Figure 9

In both cases, money grows faster than prices, which can be (tautologically) read as a positive growth of the ratio between real GDP and the velocity of circulation of money. In the Brazilian case, between 1947 and 2004 the average growth rates of money, prices and real GDP were, respectively, $87.0 \%, 84.0 \%$ and $5.1 \%$, numbers which imply an average increase of M1 velocity at the rate of $3.39 \%$ a year.

It is clear from Figure 9, by the slope of the price line, how the stabilization of inflation was successfully reached in 1994. It took democracy ten years to deliver low inflation. It is still an open question how many additional years it will take to deliver a reasonable sustained growth of the per capita income.

Figure 10 shows the evolution of $M 1$ as a fraction of the nominal GDP and inflation. 


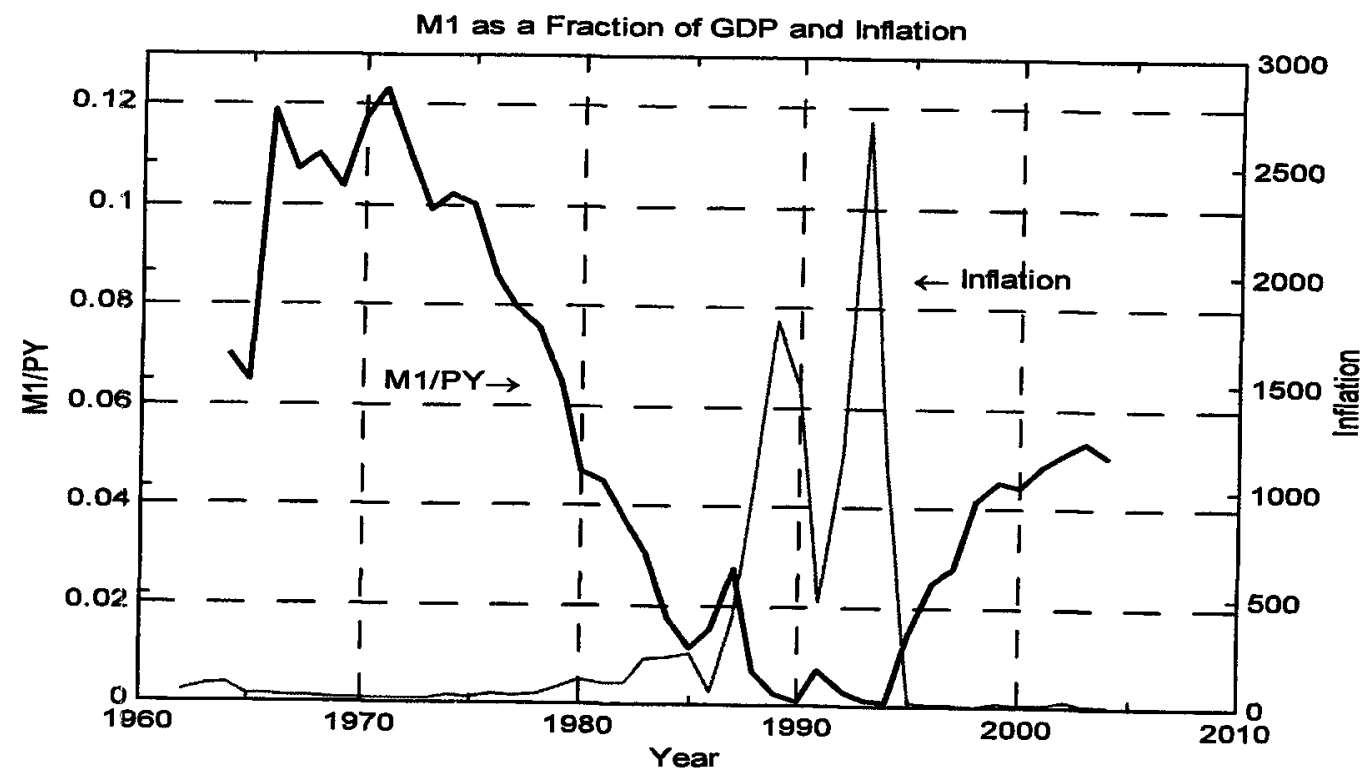

Figure 10

The ratio between $M 1$ and nominal GDP has fallen steadily from $12.7 \%$ in 1971 (because inflation increased and also because of the financial innovations introduced at this time) to less than $0.1 \%$ in the early 90s. After 1994 it recovered steadily, reaching around $5.0 \%$ in 2004 . With a money multiplier around 1.47 (average between January of 2004 and April of 2005), this implies a ratio around 3.4 between the monetary base and nominal GDP.

\section{Foreign Sector}

\section{- External Savings}

Figure 11 shows the evolution of the current account of the Brazilian balance of payments between 1947 and 2004. The outer line presents figure in Millions of U.S. dollars, whereas the inner line shows real values (in 1947 dollars). 


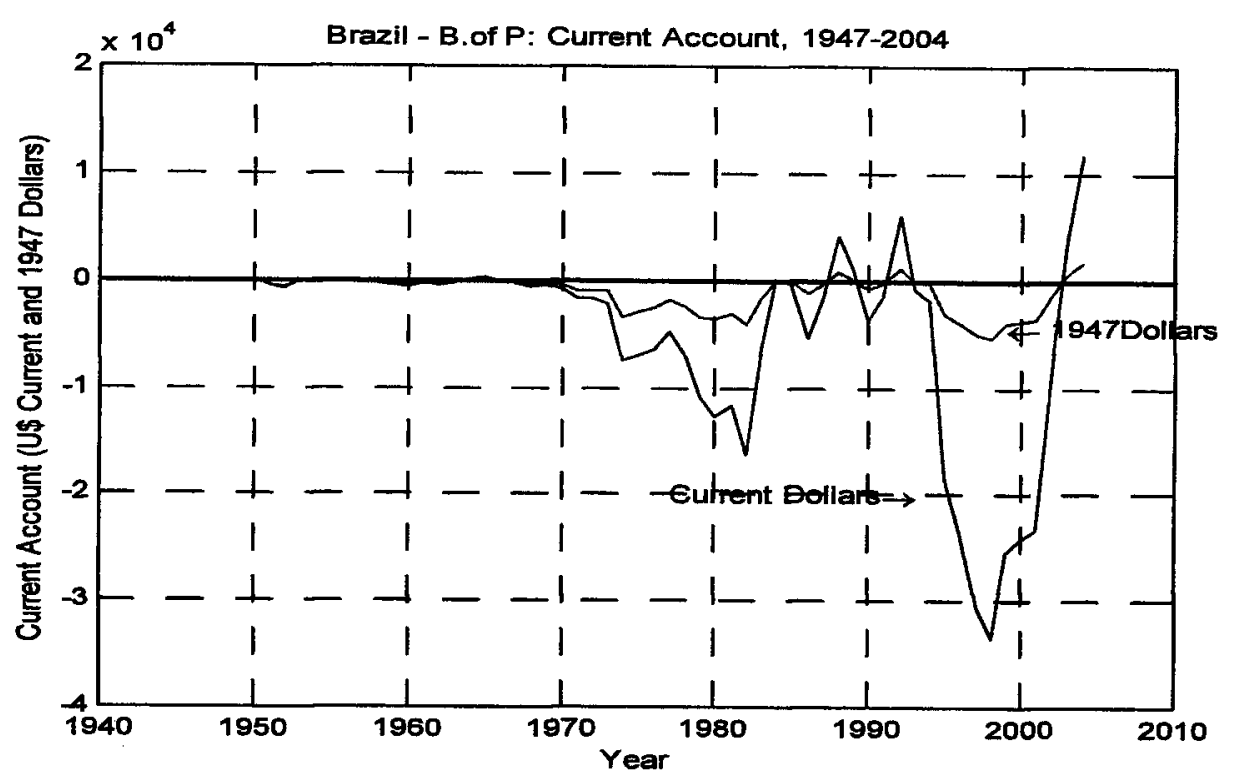

Figure 11

Between 1947 and 2004, Brazil has saved to the rest of the world in only 9 years: 1950, 1964, 1965, 1984, 1988, 1989, 1992, 2003 and 2004. In the remaining 49 years, Brazilian net external liabilities (which equal net external debt plus net foreign direct investments ${ }^{5}$ in Brazil) have increased.

The excess of internal investments over domestic savings in Brazil has been particularly high from the seventies to before the mid-eighties and between 1995 and 2002.

The highest current account deficit, both in millions of current dollars or in dollars of 1947 , occurred in 1998 (U\$33, 416 and $\mathrm{U} \$ 5,3708$, respectively). The record high until 1996, in millions of 1947 dollars, happened in 1982 (U\$ $4,0225)$.

- Net External Liabilities

The historical variation of the net external liabilities as of 1947 is shown in Figure 12 in current dollars, in 1947 dollars and as a ratio with respect to exports:

\footnotetext{
${ }^{5}$ Direct investment here, by definition, stands for the items in the capital account of the balance of payments the remuneration of which generates retained or distributed profits (dividends), rather than interests.
} 


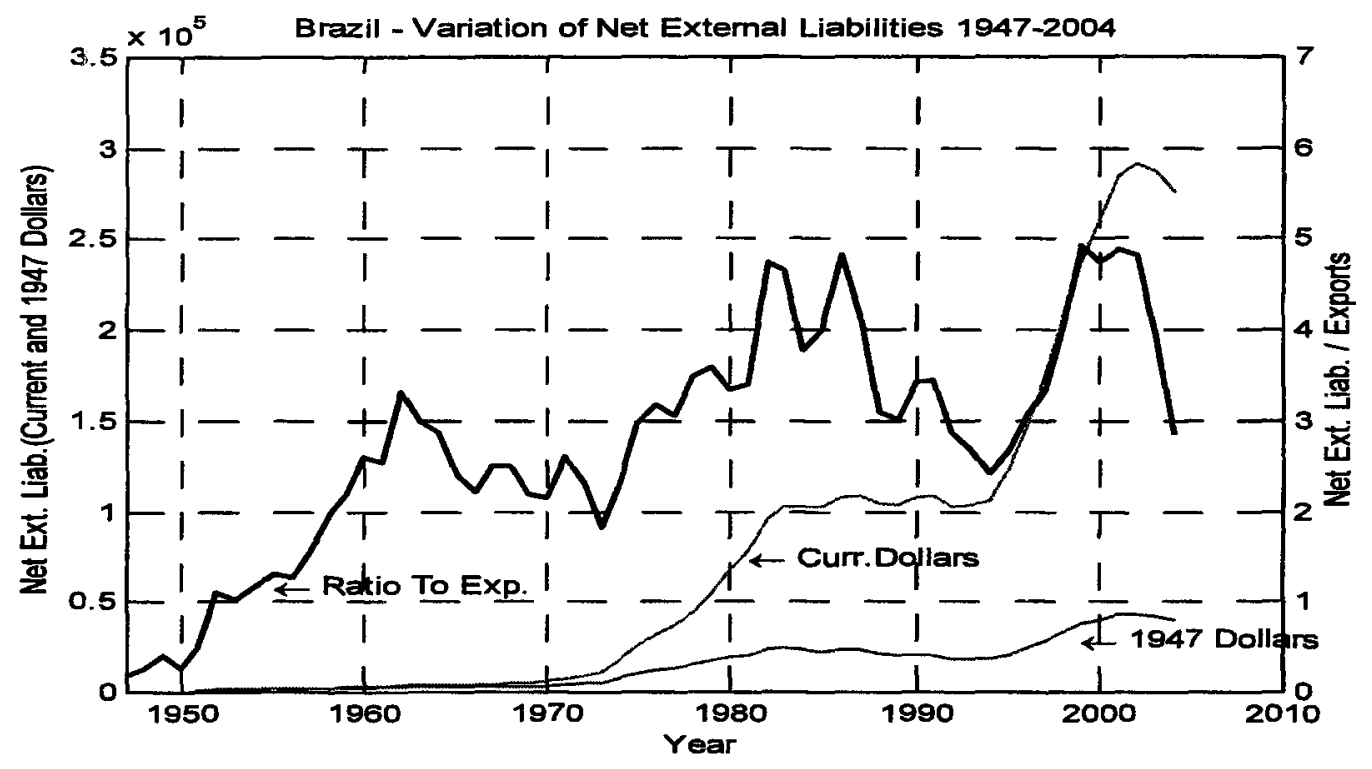

Fugure 12

Net external liabilities (in Portuguese, Passivo Externo Líquido - call it D) have reached $U \$ 67,516+D_{46}$ millions in $1980, D_{46}$ standing for the initial value of this variable in millions of current dollars, in December 31, 1946. Between 1981 and 2002, additional U\$ 224, 189 millions have been added to these liabilities, making a total of $\mathrm{U} \$ 291,705$ in the end of 2002. By subtracting the positive excess of the GNP (Gross National Product) over the internal absorption of goods and services in the years 2003 and 2004, one obtains the final figure for the net external liabilities existing at the end of 2004: U\$ $275,883+D_{46}$ millions.

The final number, of course, depends on the net external liabilities existing and the end of 1946. In current dollars, these can be considered to be negligible, in which case one obtains the final figure for the Brazilian net external hiabilities in December of $2004: U \$ 275,883^{6}$.

In order to compare the absorption of external capitals between the 1973 - 1981 years (1973 standing for the year of the first oil crisis) and

\footnotetext{
${ }^{6}$ Data of the current account of the Balance of Payment between 1930 and 1947, for instance, can be obtained from the IBGE, "Estatísticas Históricas do Brasil. Rio de Janeiro". By adding up all current account deficits between 1930 and 1946, one obtains a value of the net external liabilities in the beginning of 1947 equal to U\$ -1041.2 millions $+D_{1930}$. Here, $D_{1930}$ stands for the net external liabilities in the beginning of 1930 . The net externa! liabilities at the end of 2004 , therefore, can also be expressed as U\$ $274,841.8$ millions $+D_{1930}$.
} 
the $1994-2002$ period (1994 being the year in which the Real Plan was launched), it is appropriate that the figures above are reported in constant dollars. Using millions of dollars of 1947 , the accumulated real-value current account deficit reads a total of $U \$ 23,895$ in the years $1973-81$ and U\$ 30,031 in the years 1994-2002. In these terms, the eight years after the Real Plan have used $25.7 \%$ more external savings than the eight years after the first oil crisis (which includes the second oil crisis in 1979 and the upsurge of interest payments in the beginning of the eighties). Also in constant dollars, the period $1994-2004$ responds for $43.0 \%$ of the total accumulation of net external liabilities since $1947^{7}$.

Make $X$ denote exports. The ratio $D / X$ gives one possible measure of the exposure associated with external liabilities. In the Brazilian case, the historical peak of this ratio occurred in 1999. The value attained at this time, though, was practically equal to the one existing at the end of 1986 . At the end of 1999 a payout of net external liabilities required 59.1 months of the export revenues. At the end of 1986, 57.8 months.

Another interesting point. At the end of 2004, 34.3 months of exports were needed to liquidate the net external liabilities. This number is just slightly superior to the average one (32.0 months) existing in the three years before the Real Plan was launched $(1992-1994)$. Under this criterion, therefore, there has been no increase of the external exposure after the Real.

An alternative indicator of external indebtness uses a ratio with respect to the Gross National Product (GNP), rather than exports. Although one does not pay external liabilities with $G N P$, this is the right criterion to use when one is concerned with the average effort of a resident in Brazil to pay the country's net external liabilities. Under this alternative criterion, the numbers are as follows.

Between 1990 and 1994, under the average price of the dollar at that time, net external liabilities were worth 2.9 months of GNP. Using data of the years $1995-2004$, one obtains 4.9 months, a $69 \%$ (or 2-month) expansion. The increase seems pretty modest, when compared with the high levels of consumption enjoyed after the Real and with the achievement of having stabilized inflation.

- Exchange Rates

Figure 13 shows the evolution of exchange rates since 1947. The left

\footnotetext{
${ }^{7}$ Of course, the figure is higher $(62.40 \%)$ when the calculation is performed in current dollars.
} 
graph adds prices to the plot, whereas the right one adds both prices and money:
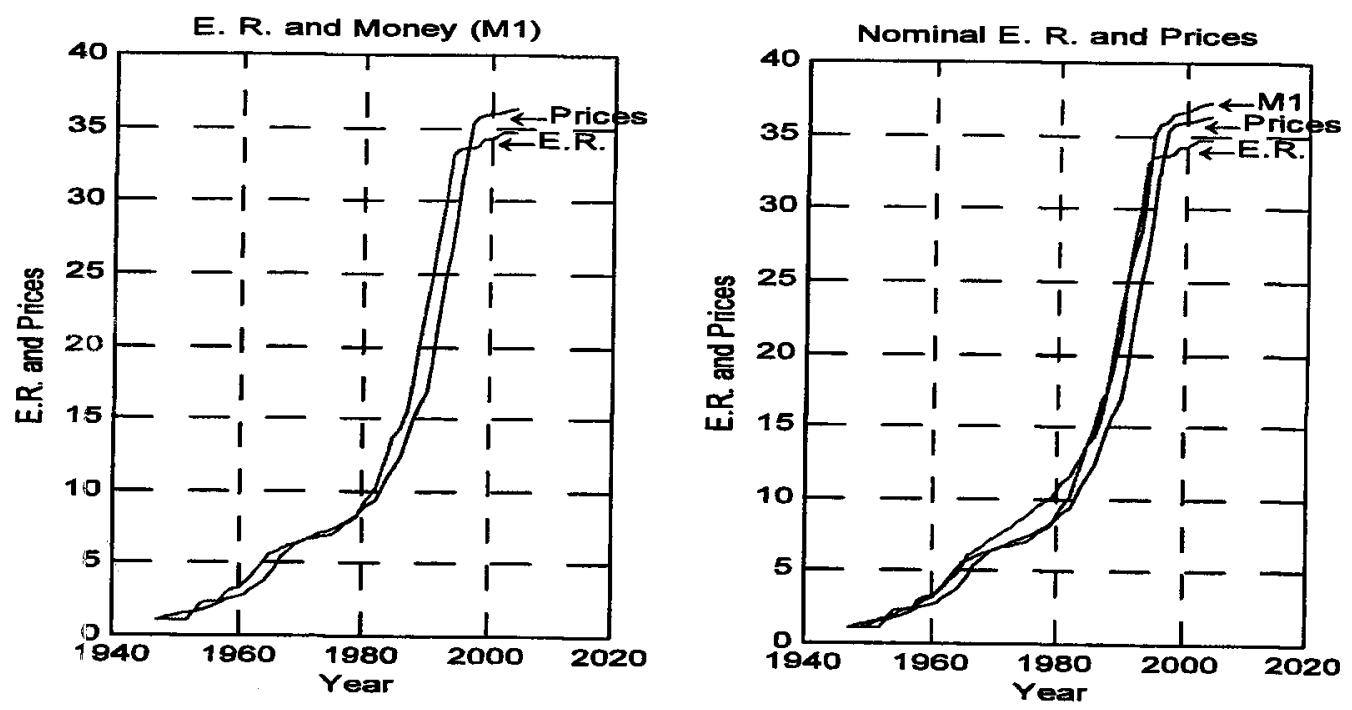

Figure 13

As it happened with money and prices, figure 13 shows a remarkable correlation between exchange rate and money or prices.

- Real Exchange Rates and Commercial Balance

Figure 14 shows the evolution of the surplus of exports over imports, in monthly values, millions of dollars, between 1980 and 2005. Both series were constructed using the HP filter. 


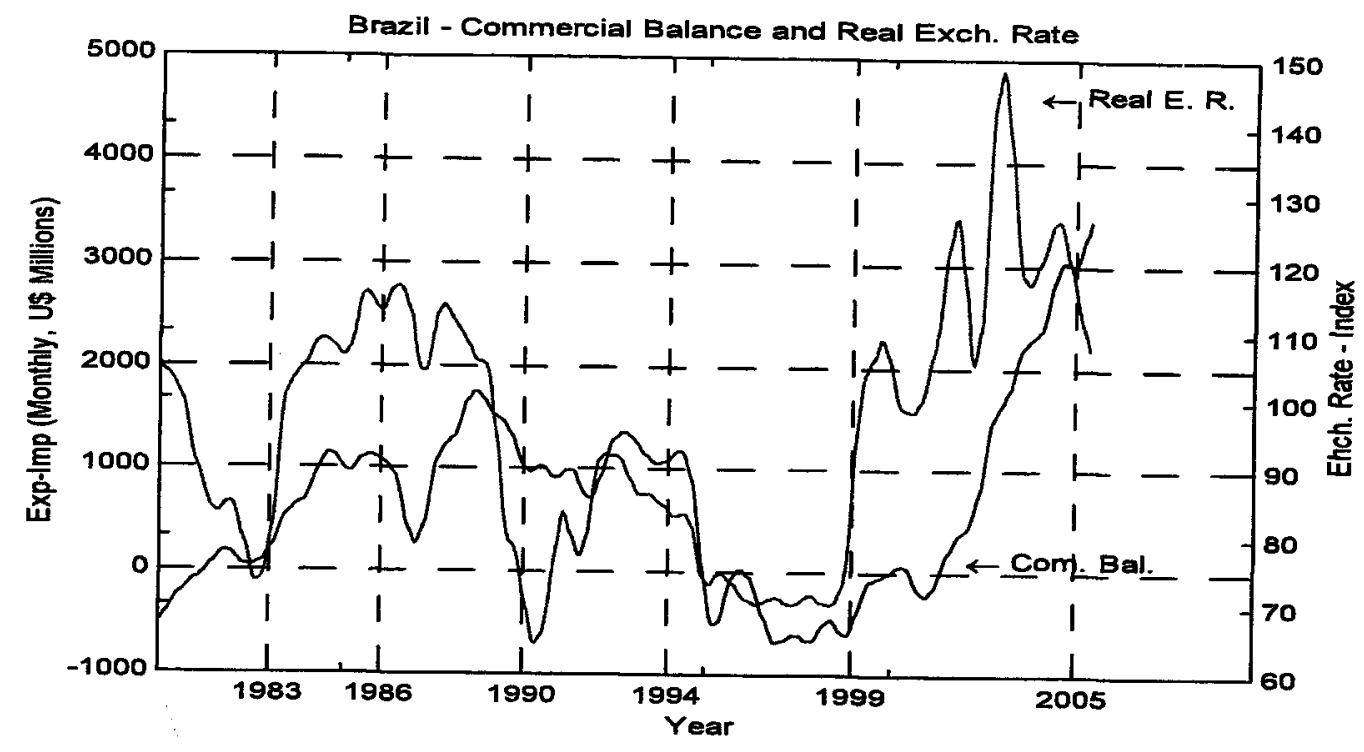

Figure 14

On the right axis one reads the real exchange rate. An important point to be noticed is the delay between changes of value of the real exchange rate and their effects over the commercial balance.

This point is particularly important in the present moment, in which the combination of high interest rates with flexible exchange rates has lead to a much lower price of the dollar than the one which happened last year. Following the trends shown in figure 14, this is supposed to generate a fall of the commercial balances in the near future, a fact that has to be taken into consideration by the present managers of economic policy.

\section{Variance Decompositions}

Figures 15 a,b and $c$ provide a variance decomposition for a VAR with log of GDP, $\log$ of prices and $\log$ of $\mathrm{M} 1$, in this order, with a four year-horizon and using, respectively, 8,4 and 1 lags:

Percentages of Forecast Error in Rows Explained by Columns

$\begin{array}{rrrr} & y & p & m \\ y & 79.96339 & 2.66195 & 17.37466 \\ p & 1.57973 & 17.84278 & 80.57749 \\ m & 3.13367 & 8.74950 & 88.11683\end{array}$

Figure 15a, Variance Decomposition, VAR with 8 Lags 
Percentages of Forecast Error in Rows Explained by Columns

$\begin{array}{rrrr} & y & p & m \\ y & 95.78056 & 0.09369 & 4.12575 \\ \mathrm{p} & 1.24292 & 2.08408 & 96.67300 \\ \mathrm{~m} & 3.09465 & 0.75747 & 96.14788\end{array}$

Figure 15b, Variance Decomposition, VAR with 4 Lags

Percentages of Forecast Error in Rows Explained by Columns

$\begin{array}{rrrr} & y & p & m \\ y & 96.26412 & 0.47568 & 3.26020 \\ \mathrm{p} & 1.21839 & 5.50960 & 93.27201 \\ \mathrm{~m} & 0.63509 & 5.06999 & 94.29492\end{array}$

Figure 15c, Variace Decomposition, VAR with 1 Lag

It is interesting to see that money explains a fraction no greater than $18 \%$ of the variance of the GDP and no lower than around $80 \%$ of the variance of prices. This order of magnitude is reasonably robust to changes in the forecast horizon. Prices, on the other hand, explain less than $6 \%$ of the variance of money.

\section{Some Open Questions}

Some points observed above require further investigations.

First, the drop in output growth as of 1980 (Figures 1 and 2). After 15 years, the country has not been able to resume its 1900-1980 historical rate of growth. Does it translate a temporary downturn or a structural change in the Brazilian pattern of growth ${ }^{8}$ ?

Several possible causes have been pointed out to explain the fall of output growth as of the early eighties. Among these are the increase of external indebtness and some bad public investment decisions occurred in the 70s (e.g., the nuclear program); decline of public investments as of the early eighties (Figures 3 and 4); inadequate economic policies at the end of 1979 (prefixation of monetary correction and nominal devaluations of the exchange rate in unfeasible levels, together with a reduction in the timing of adjustments of wages to the previous peak of purchasing-power); poor pollices

\footnotetext{
${ }^{8}$ An answer to this question, in particular, is important for the present way how the Central Barik manages monetary policy. Indeed, the current practice targets a rate of interest which is a function of the deviation of inflation from its desired level and of output from the economy's potential supply (see, e.g., Taylor (1993)).
} 
between 1980 and 1984 (e.g., the Lei da Informatica in 1984); heterodox stabilization plans carried out between 1986 and $1991^{\circ}$, which failed miserably and cluttered the economy; the difficulties to economic policy making introduced by the Constitution of $1988^{10}$ etc. The main point here, though, is not pointing to this or that reason, but understanding if a fast recovery to the old rates of real output growth is technically feasible or not, and if positive, under which policies and/or circumstances.

The precedent analysis (Figures 3,5 and 6) suggests that a shift from public current expenditures to the formation of capital is one of the important ingredients, if a return to the old growth rates is to be achieved.

Second, as Friedman (1968, p. 1) points out, some economists regard rapid growth and absence of price stability as incompatible. Brazil, however, as one can notice from Figures 1 and 9, provides a clear counter-example to this claim ${ }^{11}$. This is a country in which monetary policy has certainly not fulfilled its function (in the words of Friedman) of "preventing itself of being a major source of economic disturbance." Notwithstanding, between 1947 and 2004 , to restrict to the time period in which monetary data is available, average yearly GDP growth reached $5.1 \%$, whereas inflation presented a yearly average of $85.9 \%$. It is therefore an open question how those who see inflation and rapid growth as incompatible respond to this data.

Third, Figure 10 suggests that the remarkable increase of the velocity of circulation of money in the beginning of the seventies seems to have gone beyond the one which could be explained based only on the increase of inflation and nominal interest rates. In other words, there was a autonomous shift of the money demand as of this date. This fact has been documented initially by Cysne (1984 and 1985) and later by Rossi (1986, 2000). It remains an open question to detail how this shift in money demand has been related to the issuance of the ORTNs (Obrigações Reajustáveis do Tesouro Nacional), as of the mid sixties, of the LTNs (Letras do Tesouro Nacional), as of the early seventies, and also to the repurchase agreements, which granted much more liquidity to the public debt as of this date.

Fourth, a point of a more historical nature (or methodological; if the

\footnotetext{
${ }^{9}$ The Cruzado Plan in February in 1986, the Cruzadinho in July of 1986 (basically, a fiscal package), the Bresser Plan of mid-1987, Plano Verão (Summer Plan ) in 1989, Plano Collor I in 1990 and Plano Collor II in 1991.

${ }^{10}$ The Constitution of 1988 transferred Federal revenues to states and municipalities without reciprocities regarding the provision of public services. It also increased labor costs and the earmarking of revenues, potentially shifiting future fiscal adjustments from healthy decreases of current expenses into unhealthy increases of inefficient taxation.

${ }^{11}$ Obviously, saying that does not imply saying that the loose monetary policy followed by Brazil has somehow fostered its historical rate of growth.
} 
original series is to be questioned) between 1929 and 1933 the American GDP decreased $26.6 \%$. Brazilian GDP, on the other hand, shows a contraction of just $5.23 \%$ between 1929 and 1931 and, somewhat surprisingly, an increase of $7.73 \%$ between 1929 and 1933. Given the high dependence of the Brazilian economy on its export markets at that time, how can one account for this high GDP growth between 1929 and 1933 ?

\section{Conclusions}

This paper has aimed at presenting an overview of the Brazilian Economy covering the period 1900-2004. Besides the descriptive purpose of putting together large amounts of data in an easily recognizable way, some empirical points have been remarked, whereas others have been suggested as demanding empirical research.

Some of the subjects raised here, such as the proper identification of the potential output of the economy; the lag between real exchange rate and its effect on the commercial balances; the increase of public current expenditures and the concomitant fall of investments, have practical effects in the present management of macroeconomic policies. Others are of a more historical nature.

The main conclusions of the overall analysis have already been summarized in the introduction of the work.

\section{References}

[1] Cysne, R. P. (1984): "Macroeconomic Policy in Brazil: 1964-66×198084". Doctoral Dissertation, Graduate School of Economics, Getulio Vargas Foundation. Published by Losango SA, Rio de Janeiro.

[2] Cysne, R.P., (1985), Moeda Indexada, Revista Brasileira de Economia 39 , no. 1, Jan./Mar.,57-74.

[3] Friedman, M. (1968). The Role of Monetary Policy. The American Economic: Review, LVIII, n. 1.

[4] Braun, Steven (1990). "Estimation of Current-Quarter Gross National Product by Pooling Preliminary Labor-Market Data." Journal of Business and Economic Statistics 8, 293-304.

[5] :Clark ${ }_{y}$ Peter K. (1979). "Potential GNP in the United States, 1948-80." Review of Income and Wealth 25, 141-165. 
[6] Clark, Peter K. (1982). "Okun's Law and Potential GNP." Board of Governors of the Federal Reserve System, October.

[7] Estrella Arturo, and Frederic Mishkin (1999). "Rethinking the Role of NAIRU in Monetary Policy: Implications of Model Formulation and Uncertainty." In Monetary Policy Rules, edited by J. B. Taylor, pp. 405-430. Chicago: University of Chicago.

[8] Haddad, Claudio (1978). "Crescimento do produto real no Brasil, 19001947". Rio de Janeiro: Fundação Getúlio Vargas.

[9] Okun, Arthur (1962). "Potential Output: Its Measurement and Significance." In American Statistical Association 1962 Proceedings of the Business and Economic Section. Washington,D.C.: American Statistical Association.

[10] Rossi, J.W. (1986). "The Demand for Money in Brazil Revisited", TDI96 (IPEA/INPES, Rio de Janeiro).

[11]. Rossi, J.W. (2000). "The Demand for Money in Brazil: What Happened in the 1980s?" Journal of Development Economics 31 (1989) 357-367. North Holland

[12] Taylor, J. B. (1993). "Discretion Versus Policy Rules in Practice". Carnegie-Rochester Conference on Public Policy 39: 195-294.

\section{Appendix - Sources of the Data}

Real GDP, Brazil - Original Source, Haddad (1978) -from 1900 to 1947-, FGV and IBGE. Secondary Source, Data Bank of the Getulio Vargas Foundation.

Real GDP, U.S. - Federal Reserve Bank of St Louis (FRED)

Money - Original Source Central Bank of Brazil. Secondary Source Data Bank of the Getulio Vargas Foundation.

Prices - IGP-DI, Source, Getulio Vargas Foundation.

Current Account Deficit of the Balance of Payments - Central Bank of Brazil.

Exports - Central Bank of Brazil.

GDP-GNP = Net income transferred to Abroad - Central Bank of Brazil. GDP in current dollars - Central Bank of Brazil

Nominal Exchange Rate - Data Bank of the Getulio Vargas Foundation All Remaining Data - Ipeadata 


\section{FUNDAÇÃO GETULIO VARGAS}

\section{BIBLIOTECA}

ESTE VOLUME DEVE SER DEVOLVIDO A BIBLIOTECA NA ÚLTIMA DATA MARCADA

\begin{tabular}{l|l|l|l}
\hline & & & \\
\hline & & & \\
\hline & & & \\
\hline & & & \\
\hline & & & \\
\hline & & & \\
\hline & & & \\
\hline & & & \\
\hline & & & \\
\hline & & & \\
\hline & & & \\
\hline
\end{tabular}

98223

B|BLIOTECA

MARIO HENPIQUE SIMONSEN

FUNDACG̃O GETÚLIO VARGAS

368721

3181,2005

000368721

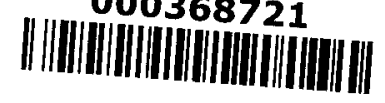

N.Cham. P/EPGE SPE C9970

Autor: Cysne, Rubens Penha

Título: An overview of some historical Brazilian

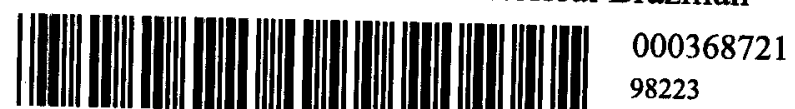

